\title{
Research Paper: Chemical Composition and Role of Opioidergic System in Antinociceptive Effect of Ziziphora Clinopodioides Essential Oil
}

\author{
Faezeh Mohammadifard $^{1}$ (D), Samad Alimohammadi ${ }^{* *}$ (D) \\ 1. Department of Basic Sciences, Faculty of Veterinary Medicine, Razi University, Kermanshah, Iran.
}

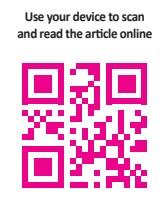

Chtation: Mohammadifard, F., \& Alimohammadi, S. (2018). Chemical Composition and Role of Opioidergic System in Antinociceptive Effect of Ziziphora Clinopodioides Essential Oil. Basic and Clinical Neuroscience, 9(5), 357-366. http://dx.doi. org $/ 10.32598 / \mathrm{bcn} \cdot 9.5 .357$

http://dx.doi.org/10.32598/bcn.9.5.357

Keywords:

Ziziphora Clinopodioides,

Antinociceptive, Opioidergic, Rat

\section{A B S T RA C T}

Introduction: Ziziphora Clinopodioides has been used widely for various therapeutic purposes in Iranian folk medicine. The current study aimed to determine interaction of antinociceptive effect of the Essential Oil of Ziziphora Clinopodioides (EOZC) and opioidergic system in male rats using formalin test.

Methods: Sixty-four male Wistar rats were divided into eight groups. The groups 1 to 7 were injected with normal saline, vehicle (Tween-80, 0.5\%), 10, 20, $40 \mathrm{mg} / \mathrm{kg}$ of the EOZC, morphine $(5 \mathrm{mg} / \mathrm{kg})$ and naloxone $(2 \mathrm{mg} / \mathrm{kg})$, respectively. Thirty minutes later, the formalin test was performed by intraplantar injection of formalin $(50 \mu \mathrm{L}, 2 \%)$. In group 8 , naloxone (2 $\mathrm{mg} / \mathrm{kg}$ ) was injected $15 \mathrm{~min}$ before injection of EOZC (20 mg/kg), followed by formalin at 15 min later. The formalin test was done as time spent for licking and biting of the injected paw. Formalin induced a biphasic pain reaction. The chemical composition of EOZC was identified using Gas Chromatography-Mass Spectrometry (GC-MS).

Results: EOZC (10, 20, and $40 \mathrm{mg} / \mathrm{kg})$ dose dependently and morphine $(5 \mathrm{mg} / \mathrm{kg})$ reduced pain responses in the both phases of pain $(\mathrm{P}<0.05)$. Naloxone $(2 \mathrm{mg} / \mathrm{kg})$ alone had no effect on the severity of pain $(\mathrm{P}>0.05)$ but pretreatment with naloxone inhibited EOZC-induced antinociception activity $(\mathrm{P}<0.05)$. Based on the GC-MS results, EOZC comprised $65.22 \%$ carvacrol, $19.51 \%$ thymol, $4.86 \%$ p-cymene and $4.63 \% \gamma$-terpinene.

Conclusion: These results demonstrate that EOZC has antinociceptive effect and this effect might mediate via opioidergic pathways.

\section{Highlights}

- Ziziphora clinopodioides Essential Oil (EOZC) exhibits antinociceptive activity in the formalin test.

- Antinociceptive effect produced by EOZC is prevented by naloxone (an opioid receptor antagonist).

- EOZC seems to act via opioidergic system in the formalin test.

\section{* Corresponding Author:}

Samad Alimohammadi, PhD

Address: Department of Basic Sciences, Faculty of Veterinary Medicine, Razi University, Kermanshah, Iran.

Tel: +98 (938) 1518467

E-mail:s.alimohammadi@razi.ac.ir 


\section{Plain Language Summary}

Pain is a displeasing sensation associated with tissue damage. Medicinal plants have been widely used in the treatment of pain. The essential oils are volatile molecules and have shown many biological activities, such as analgesic activity. In this study, we described the antinociceptive effect of the essential oil from Ziziphora clinopodioides (10, 20 , and $40 \mathrm{mg} / \mathrm{kg}$, IP). Antinociceptive activity was investigated by measuring the nociception induced by formalin. EOZC dose-dependently suppressed both phases of formalin pain. Additionally, pretreatment with naloxone reversed the antinociceptive effect of the EOZC, suggesting the involvement of opioidergic system and its receptors. These results confirm the ethnomedical uses of Ziziphora clinopodioides.

\section{Introduction}

ain is a displeasing sensation associated with tissue damage (Karimi, Monajemi, \& Amjad, 2014). Pain is a physiologic protective function occurring via an external or internal harmful stimulus (Ashok \& Upadhyaya, 2013). Activation of nociceptors in visceral structures leads to visceral pain including angina, colic, dyspepsia, pancreatitis, appendicitis, and dysmenorrhea (de Oliveira Júnior et al., 2017). Visceral tissue injury and inflammation can activate nociceptive primary afferent fibers, which results in central sensitization or hyperexcitability of nociceptive neurons in the spinal cord dorsal horn (Grace, Hutchinson, Maier, \& Watkins, 2014).

Recently, nonprescription analgesics like Non-Steroidal Anti-Inflammatory Drugs (NSAIDs) and opioids are not prescribed because of their adverse effects (Zendehdel, Torabi, \& Hassanpour, 2015). Instead, a variety of plant-derived pharmaceutical products are used in traditional medicine due to their positive properties (Yama et al., 2011). Plants are a rich source of a wide variety of secondary metabolites such as flavonoids, thymol, carvacrol, terpenoids, alkaloids (Hassanpour, Sadaghian, MaheriSis, Eshratkhah, \& ChaichiSemsari, 2011). Worldwide interest has increased on traditional medicine. People are more interested in consuming medicinal plants because of their therapeutic properties (Yousif, Ashoush, Donia, \& Hala Goma, 2013).

Pharmaceutical research is highly focused on identifying bioactive compounds in plants. Such knowledge can be used for the treatment of different conditions, such as anxiety, pain, and inflammation (de Oliveira et al., 2012). The evaluation of pharmacological effects can be used as a strategy for discovering new plant-deprived pharmaceuticals (Zendehdel, Taati, Jadidoleslami, \& Bashiri, 2011).

Medicinal and aromatic plants are traditionally used for the treatment of various illnesses (Khodaverdi-Samani, Pirbalouti, Shirmardi, \& Malekpoor, 2015). Ziziphora
Clinopodioides belongs to the Lamiaceae family. It is called "Kakuti-e-kuhi" or "Taramoshk" in Persian. This plant is spread worldwide and particularly in Iran, Afghanistan, Iraq and Turkey. Fresh leaves and stems are prescribed for wound healing and sedation. These herbs are presented in the forms of stomach tonic, antiseptic, expectorant, antifungal, antibacterial and antiseptic substances, in traditional Iranian medicine (Shahbazi, 2015).

The Essential Oil of Ziziphora Clinopodioides (EOZC) contains a diversity of biologically active compounds like monoterpenes and sesquiterpenes (Shahbazi, 2015). Most studies on rats and or mice with experimental models of pain have demonstrated that some of these terpenes have analgesic effects (Almeida, Navarro, \& Barbosa-Filho, 2001). Therefore, the current study aimed to determine the antinociceptive effect of EOZC on opioidergic system in male rats.

\section{Methods}

\subsection{Preparation of essential oil}

Fresh leaves of Ziziphora Clinopodioides were collected from Gilan-e-Gharb County (Kermanshah Province, Iran) from March to July 2016. Specimen identification was demonstrated in Faculty of Agriculture, Razi University, Kermanshah, Iran. Voucher specimen (No. 6816) of the plant was deposited in the herbaria of the Research Center of Natural Resources of Tehran, Iran.

\subsection{Isolation of essential oil}

Ziziphora Clinopodioides leaves (100 g) were shade dried at room temperature $\left(25 \pm 2^{\circ} \mathrm{C}\right)$. Samples were hydrodistilled using a Clevenger-type apparatus for $3.5 \mathrm{~h}$ till full of essential oil. Then, supernatant was collected and dried with $0.5 \mathrm{~g}$ anhydrous sodium sulfate (Merck, Darmstadt, Germany). The essential oil was stored in a dark glass bottle, and covered with aluminum foil at $4 \pm 1^{\circ} \mathrm{C}($ Shahbazi, 2015). 


\subsection{Analysis of the EOZC}

The chemical compounds of EOZC was determined by Gas Chromatography-Mass Spectrometry (GC-MS) (Thermo Quest Finningan, UK), as presented in Table 1. The GC-MS instrument was 5\% phenyl methyl silicone and 95\% dimethylpolysiloxane and equipped with DB5 capillary column $(30 \mathrm{~m}, 0.25 \mathrm{~mm}$, film thickness 0.25 $\mu \mathrm{m})$. An electron ionization mode with ionization energy of $70 \mathrm{eV}$ was used to determine the EOZC constituents (Shahbazi, 2015). The carrier gas was helium at a constant flow rate of $1.2 \mathrm{~mL} / \mathrm{min}$, with linear velocity of 29.6 $\mathrm{cm} / \mathrm{s}$ and split ratio of 1:20. The initial oven temperature was held at $50^{\circ} \mathrm{C}$ for $3 \mathrm{~min}$, then raised to $265^{\circ} \mathrm{C}$ at program ramp rate of $2.5^{\circ} \mathrm{C} / \mathrm{min}$. The final temperature was $265^{\circ} \mathrm{C}$ and maintained for $6^{\circ} \mathrm{C}$. The temperature of the injector was $250^{\circ} \mathrm{C}$. To improve accuracy of the results, the GC-MS analysis was performed in triplicate.

\subsection{Drugs}

Morphine (an opioid receptor agonist), and naloxone hydrochloride (an opioid receptor antagonist) were purchased from Sigma Chemical Co. (St. Louis, MO, USA). Tween-80 and formaldehyde (37\%) were purchased from Merck Co. (GERBU, Germany). All drugs were dissolved in normal saline. Various doses of the EOZC were prepared in Tween-80 $(0.5 \%)$. Distilled water was used to dissolve Tween- 80 into $1 \%(\mathrm{v} / \mathrm{v})$ and diluted with the same volume of normal saline. The control group were injected with vehicle. All drugs were prepared before use.

\subsection{Animals}

Sixty-four male Wistar rats (weighing: 200-220 g) were obtained from the Laboratory Animal Facility of the School of Veterinary Medicine, Razi University, Kermanshah, Iran. The animals were randomly divided into 8 groups ( 8 in each group). Rats were maintained under standard laboratory conditions according to European Guidelines for Environmental Control in Laboratory Animal Facilities (ambient temperature of $22 \pm 1^{\circ} \mathrm{C}, 12: 12 \mathrm{~h}$ light-dark cycle).

All animals had access to chow pellets and fresh water ad libitum. In group 1, animals were Intraperitoneally (IP) injected with normal saline, 30 minutes before intraplantar injection of formalin. In group 2, rats were IP injected with vehicle (Tween-80, 0.5\%), 30 minutes before intraplantar injection of formalin. In groups 3, 4 and 5, EOZC was injected IP at doses of 10,20 and $40 \mathrm{mg} / \mathrm{kg}$, respectively $30 \mathrm{~min}$ before induction of formalin pain. In groups 6 and 7, animals received IP injection of morphine $(5 \mathrm{mg} / \mathrm{kg})$ and naloxone $(2 \mathrm{mg} / \mathrm{kg})$, respectively,
30 minutes before intraplantar injection of formalin. In group 8 , animals received naloxone $(2 \mathrm{mg} / \mathrm{kg})$, then 15 min later received EOZC ( $20 \mathrm{mg} / \mathrm{kg}$ ) followed by formalin solution after $15 \mathrm{~min}$. Drug solutions were injected (1 $\mathrm{mL} / \mathrm{kg} \mathrm{IP}$ ) using a 25 -gauge injection needle.

To reduce the possible effect of circadian rhythm on the nociceptive susceptibility, all experiments were done from $9 \mathrm{AM}$ to $12 \mathrm{AM}$ (Borowicz, Kleinrok, \& Czuczwar, 2003). All experimental procedures were carried out in accordance with the guidelines for the care and use of laboratory animals to investigate experimental pain in conscious animals (Zimmermann, 1983).

\subsection{Estimation of acute toxicity}

In order to identify the acute toxicity of the essential oil with few animals, a limit test was conducted according to OECD 425 guidelines. The animals were maintained in cages for at least 5 days prior to dosing to allow adaptation to the laboratory conditions. The EOZC $(1000 \mathrm{mg} / \mathrm{kg}$ IP) was initially administered to one animal, followed by 24 hours observation. If the animal survived, 4 additional animals were sequentially administered with EOZC (1000 $\mathrm{mg} / \mathrm{kg}$, IP) under similar conditions. A total of 5 animals were tested. Observation was carried on for 14 days.

\subsection{Formalin test}

The formalin test is frequently used as a valid model of pain (Erami, Azhdari-Zarmehri, Imoto, \& Furue, 2017). To minimize the possible effect of stress during the study, rats were placed inside a Plexiglas observation chamber $\left(30 \times 30 \times 25 \mathrm{~cm}^{3}\right)$ equipped with a mirror angled at $45^{\circ}$ below the chamber for 30 minutes for 3 consecutive days (Abbott \& Bonder, 1997). In the test day, a 30-minute adaptation period was applied on the animals, prior to administrating the test. Formalin ( $50 \mu \mathrm{L}, 2 \%)$ was injected subcutaneously via a 30-gauge needle into the plantar surface of the right hind paw (Sofiabadi et al., 2014).

Following the formalin injection, rats were immediately returned to the observation chamber. The time spent on licking and biting of the injected paw was determined as nociceptive behavior. The formalin-induced behavioral responses were biphasic, as follows: 0-5 minutes (first phase, neurogenic phase) and 15-45 minutes (second phase, inflammatory phase) (Tamaddonfard \& Hamzeh-Gooshchi, 2010).

\subsection{Statistical analysis}

The obtained data were prepared in Excel and Analyzed by the Analysis of Variance (ANOVA) and Tukey's HSD 
post-hoc test using SPSS. The Student t test was employed to determine the differences between the 2 control groups of formalin test. The results were expressed as Mean \pm SEM. $\mathrm{P}<0.05$ was defined to set the significant differences between the groups.

\section{Results}

\subsection{Analysis of the EOZC}

Table 1 lists the composition of the EOZC. In total, 24 components were identified, covering 99.65\% of the total composition. Regarding the chemical constituents, carvacrol $(65.22 \%)$, thymol (19.51\%), p-cymene (4.86\%) and $\gamma$-terpinene $(4.63 \%)$ were the main components of the EOZC (Table 1).

\subsection{Acute toxicity testing}

Single dose acute toxicity of the EOZC was demonstrated through a limit test $(1000 \mathrm{mg} / \mathrm{kg}$. IP). EOZC caused no animal mortality in a period of 14 days. Therefore, LD50 of the EOZC was considered to be more than $1000 \mathrm{mg} / \mathrm{kg}$.

\subsection{Effect of the EOZC on formalin-induced pain behaviors}

The intraplantar injection of formalin $2 \%$ produced a biphasic pain-related behavior. Effects of normal saline and vehicle (Tween-80, 0.5\%) on licking and biting time of the injected paw in male rats are presented in Figure 1. No significant differences were observed on the first phase of pain in the control $(72.16 \pm 6.39 \mathrm{~s})$ and Tween-80 (0.5\%) (66.50 $\pm 5.02 \mathrm{~s})$ groups $(\mathrm{P}>0.05)$. In addition, no significant differences were observed on the second phase of pain in the control $(208.50 \pm 15.21 \mathrm{~s})$ and Tween-80 (0.5\%) (196.66 $\pm 14.43 \mathrm{~s})$ groups $(\mathrm{P}>0.05)$ (Figure 1). Therefore, the data obtained from the experimental groups were compared with vehicle treated group.

The EOZC at dose of $10 \mathrm{mg} / \mathrm{kg}$ did not show any significant effect on both first and second phases of formalin pain in comparison with vehicle treated group $(\mathrm{P}>0.05)$. However, 20 and $40 \mathrm{mg} / \mathrm{kg}$ of EOZC induced a significant reduction in the pain response compared to the vehicle group in a dose-dependent manner in both first $(39.16 \pm 3.80 \mathrm{~s}$ and $31.33 \pm 3.76 \mathrm{~s}$, respectively) and second $(121.66 \pm 10.44 \mathrm{~s}$ and $108.50 \pm 11.87 \mathrm{~s}$, respectively) phases $(\mathrm{P}<0.05)$. As expected, the standard drug morphine $(5 \mathrm{mg} / \mathrm{kg})$ significantly decreased the nociceptive response in both first $(10.33 \pm 2.61 \mathrm{~s})$ and second
$(87.00 \pm 8.05 \mathrm{~s})$ phases of formalin test, compared to vehicle treated group $(\mathrm{P}<0.05)$ (Figure 2$)$.

Based on the findings, naloxone $(2 \mathrm{mg} / \mathrm{kg})$ alone had no significant effects on both phases of formalin test $(\mathrm{P}>0.05)$. In addition, pretreatment with naloxone $(2 \mathrm{mg} / \mathrm{kg}) \mathrm{sig}$ nificantly reversed antinociception by EOZC $(20 \mathrm{mg} / \mathrm{kg})$ in the first $(58.50 \pm 3.77 \mathrm{~s})$ and second $(176.00 \pm 10.25 \mathrm{~s})$ phases of formalin test $(\mathrm{P}<0.05)$ (Figure 3 ).

\section{Discussion}

The present study investigated the antinociceptive effect of EOZC and possible involvement of opioidergic system on EOZC-induced antinociception in male rats using formalin test. Herbs and plants are widely used in traditional medicine to treat numerous illnesses due to their potentially positive effects (Sofiabadi et al., 2014) Numerous experiments have explored analgesic effects of medicinal plants (Riedel, Marrassini, Anesini, \& Gorzalczany, 2015).

To our knowledge, this is the first report on the interaction of antinociceptive effect of the EOZC and opioidergic system by the formalin test in rats. Two phases of pain were evoked by formalin injection into the hind paw of the animals. Each phase of formalin test has different mechanisms of nociception. The first phase consists of neurogenic nociception, by direct stimulation of nociceptors (via $\mathrm{C}$ fibers) to the dorsal horn of the spinal cord after substance $\mathrm{P}$ is secreted and acts as a neurotransmitter. The second phase consists of inflammatory-induced
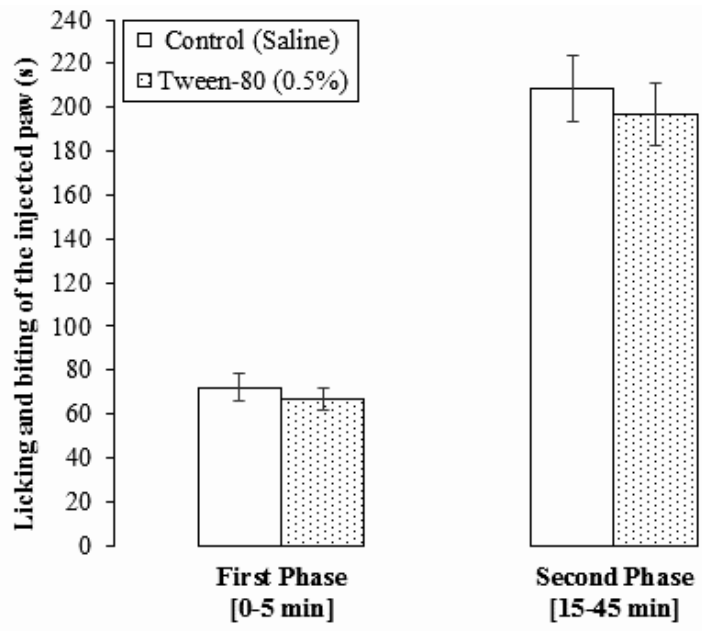

NEUR SCIENCE

Figure 1. Effect of normal saline and vehicle (Tween-80, $0.5 \%$ ) on the formalin-induced pain responses in rats

Data are expressed as Mean \pm SEM $(n=8)$. 
Table 1. The chemical composition of the essential oil of Ziziphora Clinopodioides

\begin{tabular}{|c|c|c|c|}
\hline Compounds & Composition (\%) & Retention Time (Min) & Kovats Index \\
\hline Carvacrol & 65.22 & 30.57 & 1315 \\
\hline Thymol & 19.51 & 29.61 & 1293 \\
\hline p-Cymene & 4.86 & 16.62 & 1030 \\
\hline -Terpinene & 4.63 & 18.31 & 1063 \\
\hline E-Caryophyllene & 1.07 & 35.47 & 1427 \\
\hline$\alpha$-Terpinene & 0.79 & 16.11 & 1021 \\
\hline Borneol & 0.61 & 24.36 & 1183 \\
\hline Myrcene & 0.51 & 14.62 & 992 \\
\hline Terpinene-4-ol & 0.48 & 24.7 & 1190 \\
\hline Caryophyllene oxide & 0.31 & 42.30 & 1595 \\
\hline$\alpha$-Pinene & 0.27 & 11.71 & 934 \\
\hline$\alpha$-Thujene & 0.26 & 11.33 & 927 \\
\hline Linalool & 0.13 & 20.5 & 1105 \\
\hline Camphene & 0.13 & 12.61 & 952 \\
\hline$\alpha$-Phellandrene & 0.13 & 15.58 & 1010 \\
\hline Spathulenol & 0.12 & 42.10 & 1590 \\
\hline$\beta$-Phellandrene & 0.11 & 16.89 & 1036 \\
\hline Limonene & 0.1 & 16.77 & 1033 \\
\hline$\alpha$-Terpineol & 0.08 & 25.49 & 1206 \\
\hline Terpinolene & 0.08 & 19.69 & 1089 \\
\hline 1-Octen-3-ol & 0.08 & 14.32 & 986 \\
\hline cis-Sabinene hydrate & 0.07 & 19.02 & 1077 \\
\hline$\beta$-Pinene & 0.06 & 14.06 & 981 \\
\hline Carvacrol, methyl ether & 0.04 & 27.38 & 1246 \\
\hline Total & 99.65 & & \\
\hline
\end{tabular}

NEUR:SCIENCE

pain because of release of various inflammatory mediators such as serotonin, histamine, bradykinin, Prostaglandins (PGs) and excitatory amino acids from the tissue damaged by formalin (Akbari, Mirzaei, \& Shahabi Majd, 2013; Abbott, Franklin, \& Westbrook, 1995).

Formalin test is a suitable method for generating and quantifying chemical pain in the rat model. Formalin test has long been used as a well-characterized method to evaluate antinociceptive and anti-inflammatory properties of new substances, as novel drugs continue to be developed from plants (Vissers, Hoffmann, Geenen, Biermans, \& Meert, 2003; Dubuisson \& Dennis, 1977).

Several studies suggest that the centrally acting analgesic drugs like opioids can inhibit both phases of for- 

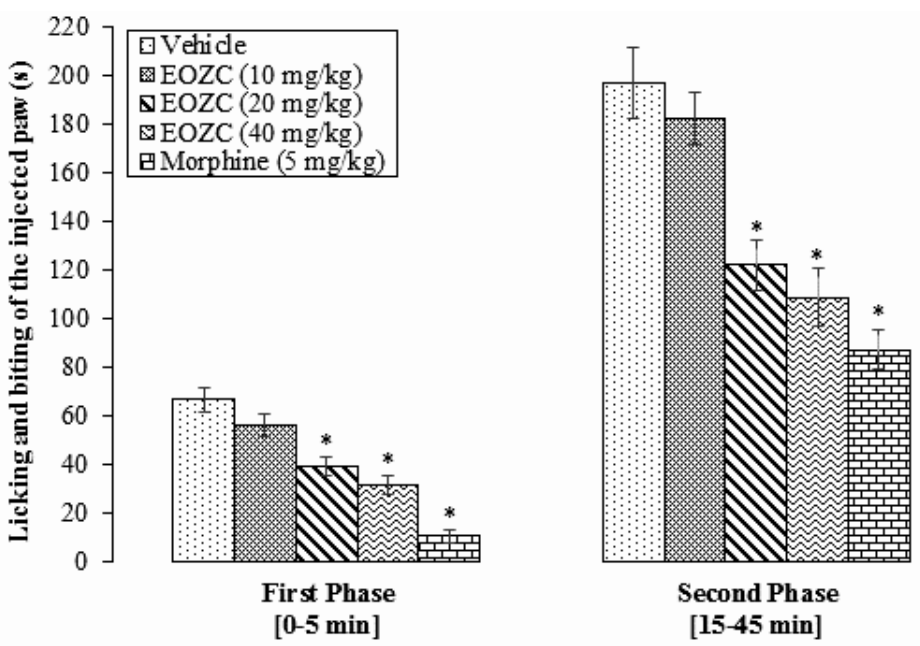

NEUR

Figure 2. Effect of different doses of the EOZC and morphine on the formalin-induced pain responses in rats

Data are expressed as mean \pm SEM $(\mathrm{n}=8)$. ${ }^{\mathrm{P}}<0.05$ : compared with vehicle test group. EOZC: Essential Oil of Ziziphora Clinopodioides.

malin test (Shibata, Ohkubo, Takahashi, \& Inoki, 1989), while peripherally acting drugs exert an inhibition only on the second phase of formalin test (Elisabetsky, Amador, Albuquerque, Nunes, \& Carvalho Ado, 1995). The IP injection of EOZC revealed a dose-dependent antinociceptive effect on both phases of formalin-induced nociception in rats. Considering the effectiveness of EOZC in suppression of paw licking time in both phases of the formalin test, it seems that the analgesic activity of $\mathrm{Z}$. clinopodioides is mediated by both peripheral and central antinociceptive mechanisms. Based on the GC-MS results, EOZC contained high concentrations of phenolic compounds including carvacrol (65.22\%), thymol (19.51\%), pcymene $(4.86 \%)$ and $\gamma$-terpinene $(4.63 \%)$. Several studies have reported the chemical composition of EOZC (Aghajani et al., 2008; Behravan et al., 2007; Ozturk \& Ercisli, 2007).

It has been shown that flavonoids and polyphenolic compounds possess a great variety of pharmacological properties
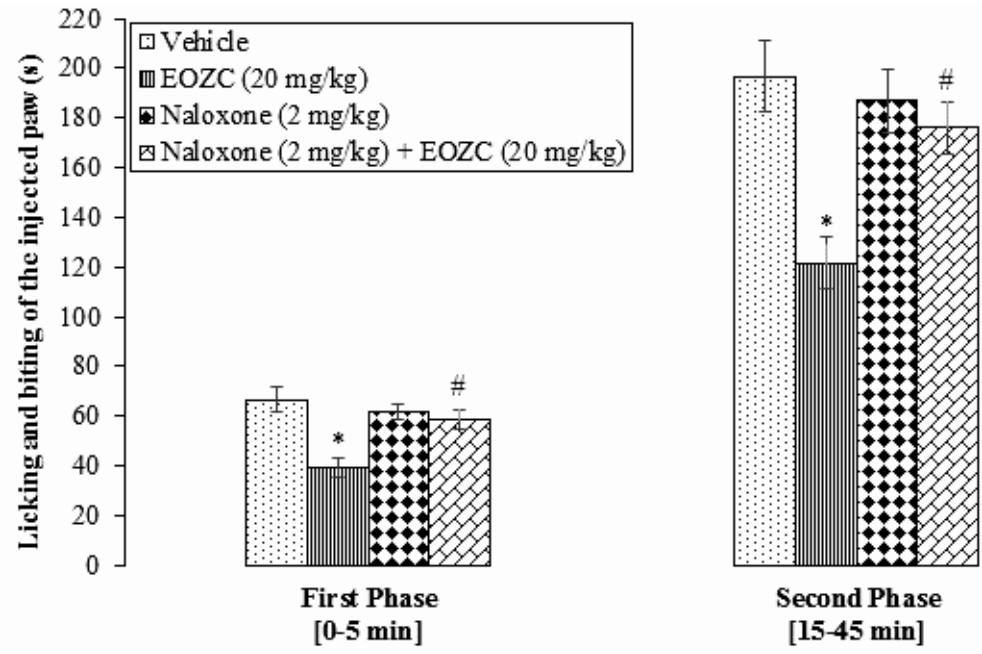

NEUR SCIENCE

Figure 3. Effect of pretreatment with naloxone on the antinociceptive activity induced by administration of EOZC in formalin pain response in rats

Data are expressed as Mean \pm SEM $(n=8)$. ${ }^{\mathrm{P}}<0.05$ : Compared with vehicle treated group. $\# \mathrm{P}<0.05$ : Compared with EOZC (20 $\mathrm{mg} / \mathrm{kg}$ ) the test group. EOZC: Essential Oil of Ziziphora Clinopodioides. 
including antioxidant activity (Altiok, Altiok, \& Tihminlioglu, 2010), immunomodulatory activity (Lima et al., 2012), inhibition of histamine release from mast cells (Amresh, Reddy, Rao, \& Singh, 2007a), and suppression of prostaglandin synthesis (Amresh, Zeashan, Rao, \& Singh, 2007b). Prior investigations suggested an antinociceptive activity for carvacrol (Guimarães et al., 2010), thymol (Beer, Lukanov, \& Sagorchev, 2007), p-cymene (De Sousa, 2011), and $\gamma$-terpinene (Hajhashemi, Sajjadi, \& Zomorodkia, 2011) in the model of formalin-induced licking. Furthermore, it is reported that thymol partially blocks voltage-operated $\mathrm{Na}+$ channels and directly activates $\mathrm{Cl}$ - currents via GABAA receptors (Haeseler et al., 2002; Mohammadi et al., 2001).

It was also expressed that thymol reversibly inhibited prostaglandin synthesis, probably related to the analgesic effect of thymol in endodontic therapy (Sarmento-Neto, do Nascimento, Felipe, \& de Sousa, 2016). There is also evidence that the antinociceptive effects of carvacrol are partly related to antioxidant activity and its scavenging activity on NO and other Reactive Oxygen Species (ROS) (Guimarães et al., 2010). Accordingly, based on the above-mentioned findings and given that these 4 compounds are among the predominant components of EOZC, it can be concluded that the antinociceptive property of EOZC might be at least in part due to the presence of these chemical compounds.

Morphine was recognized as an effective inhibitor of both phases of formalin pain. Morphine and other opioid analgesics are used for alleviating pain. The opioidergic system consists of 3 receptors including $\mu, \delta$ and $\kappa$ which are located in the central nervous system and throughout the peripheral tissues (Trescot, Datta, Lee, \& Hansen, 2008). Studies report that the endogenous opioidergic system and its receptors take part in many functions, e.g. behavior, pain and analgesia, stress, tolerance and dependence, learning and memory, alcohol and substance abuse, respiratory control, locomotion, seizures, neurological disorders and neuroendocrine physiology (Bodnar, 2016).

Naloxone (an opioid receptor antagonist) was evaluated in the formalin test to explore the effect of endogenous opioidergic system on the antinociception mechanism exerted by EOZC. Naloxone is a competitive antagonist of $\mu, \delta$ and $\kappa$ receptors, with a high affinity for the $\mu$ receptor (Trescot et al., 2008). Our findings revealed that the antinociception caused by the EOZC was significantly attenuated by the pretreatment of rats with naloxone $(2 \mathrm{mg} / \mathrm{kg})$, thus it reverses the analgesic activity of EOZC, to some extent.

The obtained results suggest that the constituents in the EOZC may act through opioidergic pathway to produce antinociceptive activity. However, further investigation is required to elucidate the underlying cellular and molecular signaling pathways.

\section{Ethical Considerations}

\section{Compliance with ethical guidelines}

Animal experiments used in this study were approved by the Animal Ethics Committee of Razi University and followed with the Guidelines for the Care and Use of Laboratory Animals in Research (Ethics code: 396-2-012).

\section{Funding}

This research was supported by a grant from the Research Council of the Faculty of Veterinary Medicine, Razi University, Iran.

\section{Authors contributions}

Authors contribution is as follows: Faezeh Mohammadifard operated the experimental procedure and animal handling. Samad Alimohammadi participated in acquisition and analysis of behavioral studies data, statistical analysis, project supervision and preparation of the manuscript.

\section{Conflicts of interest}

The authors certify that they have no affiliation with or involvement in any organization or entity with any financial interest, or non-financial interest in the subject matter or materials discussed in this manuscript.

\section{Acknowledgements}

Authors gratefully acknowledge the financial support of Razi University. We would like to express our appreciation to Dr. Shahin Hassanpour for his assistance.

\section{References}

Abbott, F. V., \& Bonder, M. (1997). Options for management of acute pain in the rat. Veterinary Record, 140(21), 553-7. [DOI:10.1136/vr.140.21.553] [PMID]

Abbott, F. V., Franklin, K. B., \& Westbrook, R. F. (1995). The formalin test: Scoring properties of the first and second phases of the pain response in rats. Pain, 60(1), 91-102. [DOI:10.1016/0304-3959(94)00095-V]

Aghajani, Z., Assadian, F., Masoudi, S., Chalabian, F., Esmaeili, A., Tabatabaei Anaraki, M., et al. (2008). Chemical composition and in vitro antibacterial activities of the oil of Ziziphora Clinopodioides and Z. capitata subsp. capitata from Iran. Chem- 
istry of Natural Compounds, 44(3), 387-9. [DOI:10.1007/s10600008-9073-4]

Akbari, E., Mirzaei, E., \& Shahabi Majd, N. (2013). Long-term morphine-treated rats are more sensitive to antinociceptive effect of diclofenac than the morphine-naive rats. Iranian Journal of Pharmaceutical Research, 12(1), 175-84. [PMID] [PMCID]

Almeida, R. N., Navarro, D. S., \& Barbosa-Filho, J. M. (2001). Plants with central analgesic activity. Phytomedicine, 8(4), 31022. [DOI:10.1078/0944-7113-00050] [PMID]

Altiok, D., Altiok, E., \& Tihminlioglu, F. (2010). Physical, antibacterial and antioxidant properties of chitosan films incorporated with thyme oil for potential wound healing applications. Journal of Materials Science: Materials in Medicine, 21(7), 2227-36. [DOI:10.1007/s10856-010-4065-x] [PMID]

Amresh, G., Reddy, G. D., Rao, Ch. V., \& Singh, P. N. (2007a). Evaluation of anti-inflammatory activity of Cissampelos pareira root in rats. Journal of Ethnopharmacology, 110(3), 526-31. [DOI:10.1016/j.jep.2006.10.009] [PMID]

Amresh, G., Zeashan, H., Rao, Ch. V. R., \& Singh, P. N. (2007b). Prostaglandin mediated anti-inflammatory and analgesic activity of Cissampelos pareira. Acta Pharmaceutica Sciencia, 49(2), 153-60

Ashok, P. K., \& Upadhyaya, K. (2013). Evaluation of analgesic and anti-inflammatory activities of aerial parts of Artemisia vulgaris L. in experimental animal models. Journal of Biologically Active Products from Nature, 3(1), 101-5. [DOI:10.1080/22 311866.2013.782761]

Beer, A. M., Lukanov, J., \& Sagorchev, P. (2007). Effect of thymol on the spontaneous contractile activity of the smooth muscles. Phytomedicine, 14(1), 65-9. [DOI:10.1016/j. phymed.2006.11.010] [PMID]

Behravan, J., Ramezani, M., Hassanzadeh, M. K., Eskandari, M., Kasaian, J., \& Sabeti, Z. (2007). Composition, antimycotic and antibacterial activity of Ziziphora Clinopodioides Lam. essential oil from Iran. Journal of Essential Oil Bearing Plants, 10(4), 33945. [DOI:10.1080/0972060X.2007.10643565]

Bodnar, R. J. (2016). Endogenous opiates and behavior. Peptides, 75, 18-70. [DOI:10.1016/j.peptides.2015.10.009] [PMID]

Borowicz, K. K., Kleinrok, Z., \& Czuczwar, S. J. (2003). Influence of sex hormone antagonists on the anticonvulsant action of conventional antiepileptic drugs against amygdala-kindled seizures in male and female rats. European Neuropsychopharmacology, 13(4), 257-65. [DOI:10.1016/S0924-977X(03)00013-0]

de Oliveira, A. M., Conserva, L. M., de Souza Ferro, J. N., de Almeida Brito, F., Lyra Lemos, R. P., \& Barreto, E. (2012) Antinociceptive and anti-inflammatory effects of octacosanol from the leaves of Sabicea grisea var. Grisea in mice. International Journal of Molecular Sciences, 13(2), 1598-611. [DOI:10.3390/ijms13021598] [PMID] [PMCID]

de Oliveira Júnior, R. G., Ferraz, C. A. A., Silva, J. C., de Oliveira, A. P., Diniz, T. C., E Silva, M. G., et al. (2017). Antinociceptive effect of the essential oil from croton conduplicatus kunth (Euphorbiaceae). Molecules, 22(6), 900. [DOI:10.3390/mole ecules22060900]

De Sousa, D. P. (2011). Analgesic-like activity of essential oils constituents. Molecules, 16(3), 2233-52. [DOI:10.3390/moll ecules16032233] [PMID]
Dubuisson, D., \& Dennis, S. G. (1977). The formalin test: A quantitative study of the analgesic effects of morphine, meperidine, and brain stem stimulation in rats and cats. Pain, 4(2), 161-74. [DOI:10.1016/0304-3959(77)90130-0]

Elisabetsky, E., Amador, T. A., Albuquerque, R. R., Nunes, D. S., \& Carvalho Ado, C. (1995). Analgesic activity of Psychotria colorata (Willd. ex R. \& S.) Muell. Arg. alkaloids. Journal of Ethnopharmacology, 48(2), 77-83. [DOI:10.1016/03788741(95)01287-N]

Erami, E., Azhdari-Zarmehri, H., Imoto, K., \& Furue, H. (2017) Characterization of nociceptive behaviors induced by formalin in glabrous and hairy skin of the rat. Basic and Clinical Neuroscience, 8(1), 37-42. [DOI:10.15412/J.BCN.03080105]

Grace, P. M., Hutchinson, M. R., Maier, S. F., \& Watkins, L. R. (2014). Pathological pain and the neuroimmune interface. $\mathrm{Na}$ ture Reviews Immunology, 14(4), 217-31. [DOI:10.1038/nri3621] [PMID] [PMCID]

Guimarães, A. G., Oliveira, G. F., Melo, M. S., Cavalcanti, S. C., Antoniolli, A. R., Bonjardim, L. R., et al. (2010). Bioassay-guided evaluation of antioxidant and antinociceptive activities of carvacrol. Basic \& Clinical Pharmacology \& Toxicology, 107(6), 949-57. [DOI:10.1111/j.1742-7843.2010.00609.x] [PMID]

Haeseler, G., Maue, D., Grosskreutz, J., Bufler, J., Nentwig, B. Piepenbrock, S., et al. (2002). Voltage-dependent block of neuronal and skeletal muscle sodium channels by thymol and menthol. European Journal of Anaesthesiology, 19(8), 571-79. [DOI:10.1097/00003643-200208000-00005] [PMID]

Hajhashemi, V., Sajjadi, S. E., \& Zomorodkia, M. (2011). Antinociceptive and anti-inflammatory activities of Bunium persicum essential oil, hydroalcoholic and polyphenolic extracts in animal models. Pharmaceutical Biology, 49(2), 146-51. [DOI:10.3 109/13880209.2010.504966] [PMID]

Hassanpour, S., Sadaghian, M., MaheriSis, N., Eshratkhah, B., \& ChaichiSemsari, M. (2011). Effect of condensed tannin on controlling faecal protein excretion in nematode-infected sheep: In vivo study. Journal of Animal Science, 7, 896-900.

Karimi, H., Monajemi, R., \& Amjad, L. (2014). Analgesic and anti-inflammatory effects of artemisia deserti krasch (Extract in rats). International Journal of Basic Sciences \& Applied Research, $3(1), 1-6$.

Khodaverdi-Samani, H., Pirbalouti, A. G., Shirmardi, H. A., \& Malekpoor, F. (2015). Chemical composition of essential oils of Ziziphora Clinopodioides Lam. (Endemic Iranian herb) collected from different natural habitats. Indian Journal of Traditional Knowledge, 1(1), 57-62.

Lima, D. K., Ballico, L. J., Lapa, F. R., Gonçalves, H. P., de Souza, L. M., Iacomini, M., et al. (2012). Evaluation of the antinociceptive, anti-inflammatory and gastric antiulcer activities of the essential oil from Piper aleyreanum C.DC in rodents. Journal of Ethnopharmacology, 142(1), 274-82. [DOI:10.1016/j. jep.2012.05.016] [PMID]

Mohammadi, B., Haeseler, G., Leuwer, M., Dengler, R., Kramp$\mathrm{fl}, \mathrm{K} .$, \& Bufler, J. (2001). Structural requirements of phenol derivatives for direct activation of chloride currents via GABAA receptors. European Journal of Pharmacology, 421(2), 85-91. [DOI:10.1016/S0014-2999(01)01033-0]

OECD. (2008). Test No. 425: Acute oral toxicity: Up-and-down procedure. In OECD publishing (Eds.), OECD Guidelines for the Testing of Chemicals, Section 4 (pp. 1-27). Paris: OECD publishing. 
Ozturk, S., \& Ercisli, S. (2007). Antibacterial activity and chemical constitutions of Ziziphora Clinopodioides. Food Control, 18(5) 535-40. [DOI:10.1016/j.foodcont.2006.01.002]

Riedel, R., Marrassini, C., Anesini, C., \& Gorzalczany, S. (2015). Anti-inflammatory and antinociceptive activity of Urera aurantiaca. Phytotherapy Research, 29(1), 59-66. [DOI:10.1002/ ptr.5226] [PMID]

Sarmento-Neto, J. F., do Nascimento, L. G., Felipe, C. F., \& de Sousa, D. P. (2016). Analgesic potential of essential oils. Molecules, 21(1), E20. [DOI:10.3390/molecules21010020]

Shahbazi, Y. (2015). Chemical composition and in vitro antibacterial effect of Ziziphora Clinopodioides essential oil. Pharmaceutical Sciences, 21(2), 51-6. [DOI:10.15171/PS.2015.17]

Shibata, M., Ohkubo, T., Takahashi, H., \& Inoki, R. (1989). Modified formalin test: Characteristic biphasic pain response. Pain, 38(3), 347-52. [DOI:10.1016/0304-3959(89)90222-4]

Sofiabadi, M., Azhdari-Zarmehri, H., Naderi, F., GhalandariShamami, M., Sonboli, A., \& Haghparast, A. (2014). Effects of hydroalcoholic extract of tanacetum sonbolii (Asteraceae) on pain-related behaviors during formalin test in mice. Basic and Clinical Neuroscience, 5(2), 162-8. [PMID] [PMCID]

Tamaddonfard, E., \& Hamzeh-Gooshchi, N. (2010). Effect of crocin on the morphine-induced antinociception in the formalin test in rats. Phytotherapy Research, 24(3), 410-3. [DOI:10.1002/ptr.2965] [PMID]

Trescot, A. M., Datta, S., Lee, M., \& Hansen, H. (2008). Opioid pharmacology. Pain Physician, 11 (2 Suppl), S133-53.

Vissers, K., Hoffmann, V., Geenen, F., Biermans, R., \& Meert, T. (2003). Is the second phase of the formalin test useful to predict activity in chronic constriction injury models? A pharmacological comparison in different species. Pain Practice, 3(4), 298-309. [DOI:10.1111/j.1530-7085.2003.03033.x] [PMID]

Yama, O. E., Duru, F. I., Oremosu, A. A., Osinubi, A. A., Noronha, C. C., \& Okanlawon, A. O. (2011). Sperm quotient in sprague-dawley rats fed graded doses of seed extract of momordica charantia. Middle East Fertility Society Journal, 16(2), 154-8. [DOI:10.1016/j.mefs.2011.02.001]

Yousif, E. I., Ashoush, I. S., Donia, A. A., \& Hala Goma, K. A. (2013). Critical control points for preparing chicken meals in a hospital kitchen. Annals of Agricultural Science, 58(2), 203-11. [DOI:10.1016/j.aoas.2013.07.004]

Zendehdel, M., Taati, M., Jadidoleslami, M., \& Bashiri, A. (2011) Evaluation of pharmacological mechanisms of antinociceptive effect of teucrium polium on visceral pain in mice. Iranian Journal of Veterinary Research, 12(4), 292-7.

Zendehdel, M., Torabi, Z., \& Hassanpour, S. (2015). Antinociceptive mechanisms of Bunium persicum essential oil in the mouse writhing test: Role of opioidergic and histaminergic systems. Veterinarni Medicina, 60(2), 63-70. [DOI:10.17221/7988-VETMED]

Zimmermann, M. (1983). Ethical guidelines for investigations of experimental pain in conscious animals. Pain, 16(2), 109-10. [DOI:10.1016/0304-3959(83)90201-4] 
